\title{
HABITAT PREFERENCE MODELING OF PREHISTORIC GIANT SHARK MEGALODON DURING MIOCENE IN BENTANG FORMATION OF WEST JAVA COAST
}

\author{
Andriwibowo $^{1 *}$, Adi Basukriadi ${ }^{2}$, Erwin Nurdin $^{3}$, Muh Aydava Mubarok ${ }^{4}$
}

Selected paper from the 6h Seminar
Nasional Biologi (SEMABIO),
Bandung-Indonesia, July 15, 2021
(conference.bio.uinsgd.ac.id)
Received : September 26, 2021
Accepted : November 23, 2021

DOI: $10.15575 /$ biodjati. v6i2.14115

1,2,3,4 Department of Biology, Faculty of Mathematics and Natural Sciences, Universitas Indonesia, Pondok Cina, Beji, Depok City, West Java 16424, Indonesia

e-mail:

*1pemodelandatabio2020@gmail.com

²basukriadi1958@gmail.com

3erwinnurdin0711@gmail.com

4muh.aydava@ui.ac.id

*Corresponding author

\begin{abstract}
In the Miocene era about 20 million years ago, the South Coast of West Java was a sea and habitat for marine organisms including giant sharks Megalodon measuring about 18 meters long. This study aimed to model the habitat preference of the prehistoric gigantic shark Otodus megalodon population based on the fossil record. From fossil teeth, it revealed that the rock layer where the teeth found was Bentang formation from Miocene era. Many fossils of Megalodon had been unearthed from Bentang formation which is part of the South Coast of West Java. The habitat model was developed using the Sea Level Rise Inundation Tool of ArcGIS to estimate the sea depth and Megalodon's habitat during the Miocene. The length of the teeth of $O$. megalodon found was ranged from 13 to $19 \mathrm{~cm}$, indicating the presence of juvenile and adult O. megalodon. Based on the model, in the Miocene era, half of West Java was a sea with a depth ranging from 0 to 200 meters. At that time, it was estimated that juvenile $O$. megalodon occupied waters with a depth of 0-40 meters with an area of $1365 \mathrm{~km}^{2}$. Meanwhile, adult O. megalodon prefers a depth of 80 $160 \mathrm{~m}$ and the frequency of habitat use increases at a depth of $200 \mathrm{~m}$. The declining population of $O$. megalodon is associated with climate change and declining prey populations.
\end{abstract}

Keywords: depth, habitat, model, shark, tooth

\section{Citation}

Andriwibowo, Basukriadi, A. \& Nurdin, E. (2021). Habitat Preference Modeling of Prehistoric Giant Shark Megalodon During Miocene in Bentang Formation of West Java Coast. Jurnal Biodjati, 6(2), 264-272.

\section{INTRODUCTION}

In the prehistoric era, giant animals were inhabiting both terrestrial and aquatic ecosystems, including the ocean. In the vast prehistoric marine ecosystems, there were also gigantic fish species including megalodon shark. An extinct giant shark, scientifically name Otodus megalodon (previously known as Charcarocles megalodon), is the last member of the predatory mega-toothed lineage and is reported from the Miocene (20 million years ago) to Pliocene periods from nearly all continents (Boessenecker, et al. 2019, Cooper, et al. 2020). Based on fossil records, the global $O$. megalodon distributions are including South America (Bahia Inglesa, Mina Fosforita, Punta la Gorda, Punta la Colorada,), Britain (Beaumaris), Australia (Batesford), North America (Tamiami, Gatun), Europe (Romania), Africa, and New Zealand (Wellington) (Keyes, 1972, 


\section{JURNAL BIDDJATI}

http://journal.uinsgd.ac.id/index.php/biodjati

Pimiento, et al. 2016, Trif, et al. 2016). Those fossils were found either on coasts or in lands, which indicates that during prehistoric periods a terrestrial land today was the bottom of the sea. A process called continental drift has caused the bottom of the sea to become dry land as can be seen today. Despite its global distribution, reports of $O$. megalodon in Asia continents are still limited with the only report published from the coast of Brunei (Kocsis \& Razak, 2018).

Java is known as one of the islands in South East Asia with a high diversity of prehistoric periods animals. In this land, several prehistoric animals fossils have been found. However, records on aquatic prehistoric animals are still scarce. This is contradicted by the geographical fact that Java Island is surrounded by sea and ocean. Today, the sea around Java Island has vast biodiversity including extant sharks accounted for 118 species under 25 families (Yudha, et al. 2018). Here, this study aimed to explore the presence of megalodon and model the habitat preference of this species mainly in Java Island. The Bentang formation is selected because this formation was formed during the Miocene era when the megalodon was present (Gaffar, 2017, Syahied, et al. 2020).

\section{MATERIALS AND METHODS}

The study area was the South Coast of West Java (Figure 1). The coastal area was selected based on the lithographic characteristic that represents the Miocene period. The South Coast of Java Island was bordered directly with the Indian Ocean, the ocean with its vast areas where suitable habitats for large sharks. The material used to assess the large shark presence was a fossil identified as $O$. megalodon and tooth fossil specimens were collected through excavation methods following Satria et al. (2018). The tooth was excavated from sediment collected within multiple $2 \times 2 \mathrm{~m}$ excavation grids. The sediments were then wet-sieved to obtain the tooth (Veatch, et al. 2019). The excavated tooth was compared with results from Herraiz et al. (2020) for identification purposes based on tooth shape and morphological characters. The teeth were identified to the species level and examined with 10x and 40x magnification to identify general patterns consistent with the previous study. Method to identify sediment and geological rock layer formation where the fossil was excavated following Gaffar (2017).

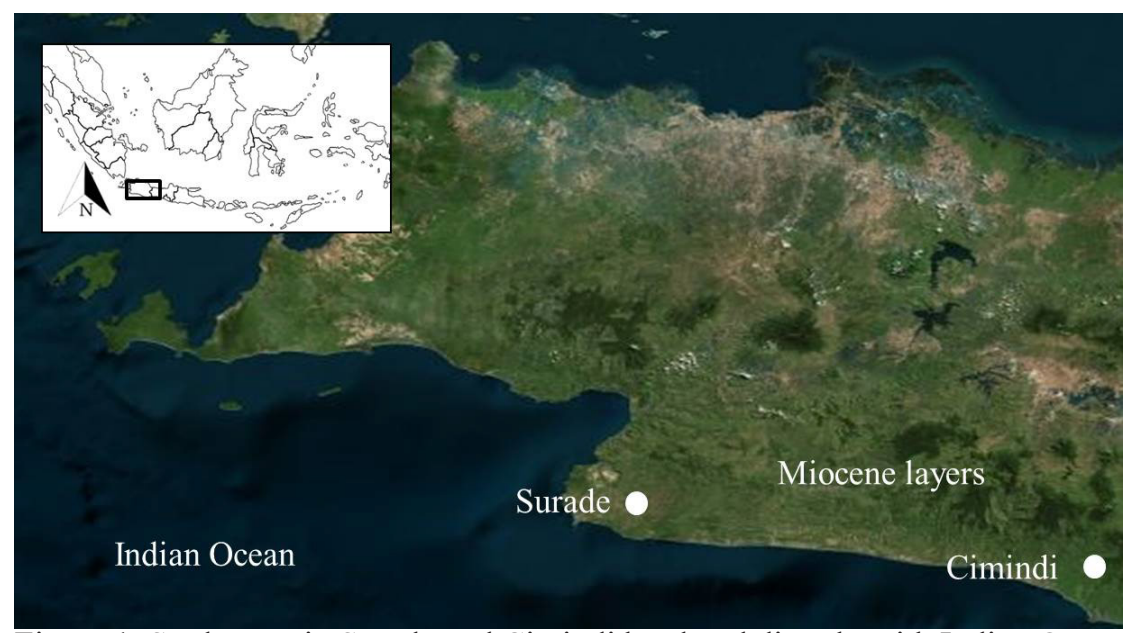

Figure 1. Study area in Surade and Cimindi bordered directly with Indian Ocean in the South 


\section{JURNAL BIDDJATI}

http://journal.uinsgd.ac.id/index.php/biodjati

The prehistoric Miocene Ocean in the South Coast of West Java was reconstructed referred to the location where the megalodon fossil was found and followed the method by Levy et al. (2019). The modeled Miocene Ocean was then used to estimate the habitat of extinct megalodon. Megalodon habitat was estimated by comparing habitat used by the extant great white shark (Carcharodon carcharias) as the only modern analog. $C$. carcharias is selected as an analog because it is the largest extant shark predator today that is comparable to the megalodon during the Miocene era. Habitat modeling was made for juvenile and adult megalodons using the water depth as the function of habitat use preference. The habitat and water depth were modeled using the Sea Level Rise Inundation Tool of ArcGIS.

\section{RESULTS AND DISCUSSION}

This study is the first that has reported the presence of megalodon in South East Asia. Along with the first record, a habitat use preference of megalodon has been developed. During the Miocene period, 20 million years ago, the Bentang formation of the South Coast of West Java Island was submerged and became part of the Indian Ocean and provided suitable habitats for the megalodon population.

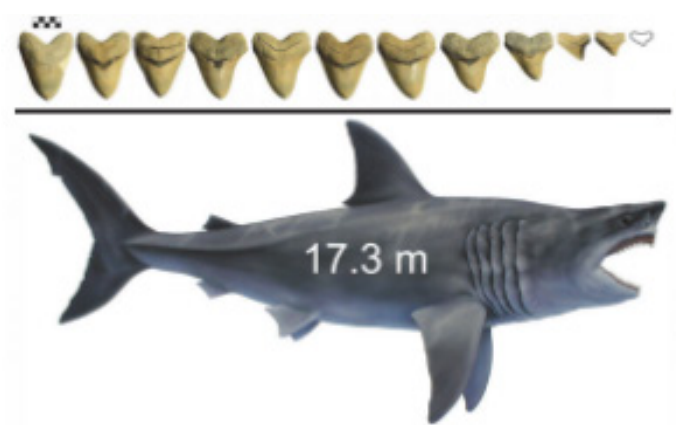

In the South Coast of West Java, there were 2 particular locations where megalodon teeth fossils can be found. Those locations were Surade in West and Cimindi Villages in East, separated $200 \mathrm{~km}$ from each other. The Surade and Cimindi village are located $5 \mathrm{~km}$ and $15 \mathrm{~km}$ from the Indian Ocean, respectively. The megalodon tooth excavated was sizing 13-19 cm for its length and 14 for its base (Figure 2). Based on the illustration in Figure 3, with tooth sizing 13-19 cm, it is estimated the size of the megalodon was approximately $15 \mathrm{~m}$ long and might reach its maximum size of $17.9 \mathrm{~m}$. In Surade, the teeth were deposited in rock and soil layers. Based on lithological records, the soil and rock layers were within Bentang Formation from the Miocene period (Figure 4). According to Azizah (2020) and Syahied et al. (2020), the Bentang Formation dominating the South Coast of West Java was developed in mid of Miocene period and this period is matched to the existence and prehistoric time when megalodon has existed.

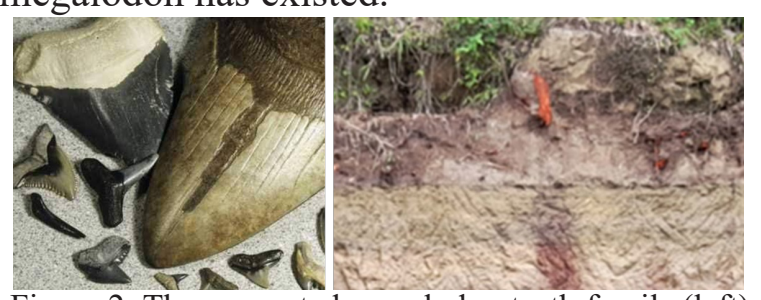

Figure 2. The excavated megalodon teeth fossils (left) and soil rock layers (right) containing fossils in Surade in South Coast of West Java.

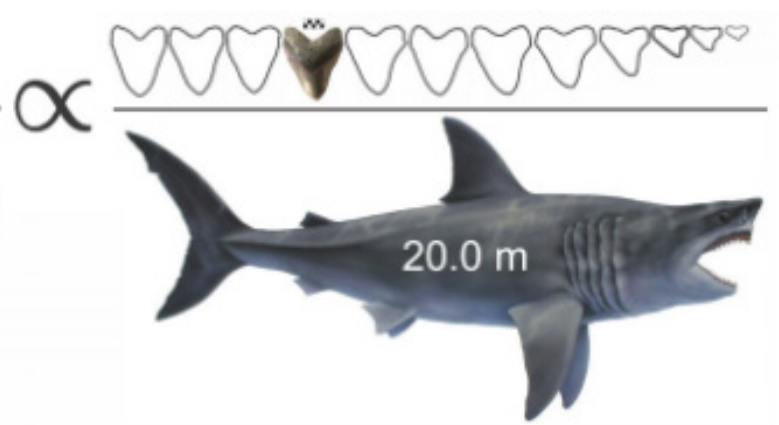

Figure 3. Illustration depicting the teeth and body length of Otodus megalodon (Perez, et al. 2021) 


\section{JURNAL BIODJATI}

http://journal.uinsgd.ac.id/index.php/biodjati

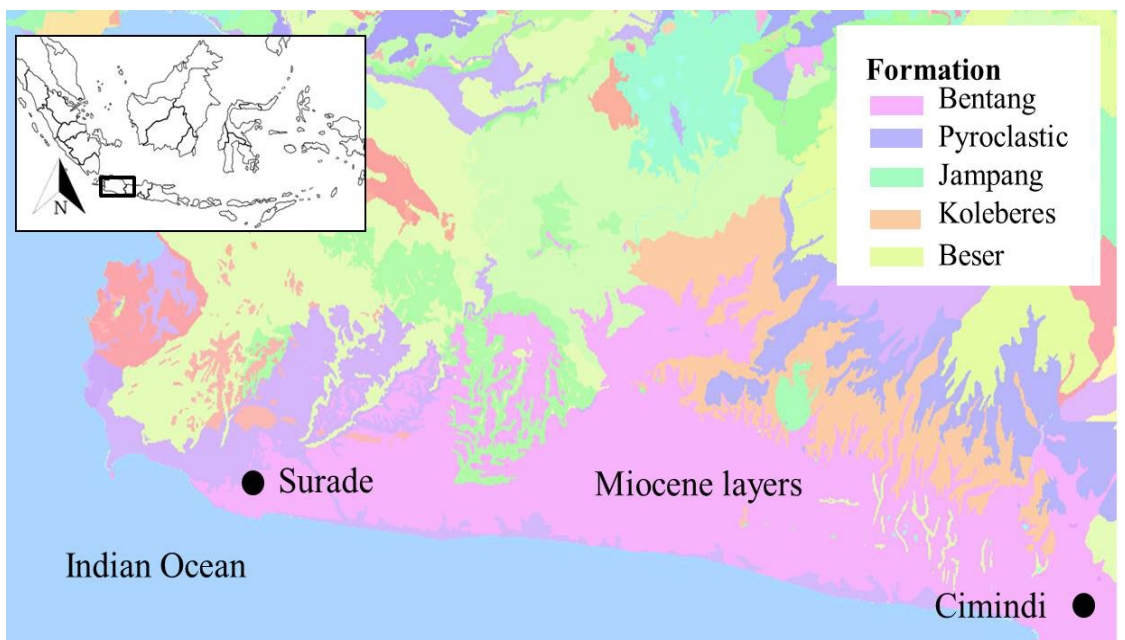

Figure 4. The localities of megalodon tooth fossils in Surade and Cimindi Villages in Miocene layers of Bentang

Based on prehistoric ocean modeling, the Surade and Cimindi Villages were submerged by the ocean during the Miocene period. In fact, 20 million years ago (Ma), almost half of the Java Island was an ocean with the Miocene period coastline being located 50 $\mathrm{km}$ from the current coastline (Figure 5). The South Coast of Java was then modeled with ocean submersion at depth of $40 \mathrm{~m}$. In this model, one of the megalodon fossil localities in Surade is already submerged by the Indian Ocean (Figure 6). The submersion model then was developed up to $200 \mathrm{~m}$ depth referring to the depth of the megalodon habitat. At this depth, half of the South Coasts of West Java were submerged and become parts of the Indian Ocean referring to the past Miocene period (Figure 7). The submersion model was presented in the bathymetry model and the Miocene coast was located $50 \mathrm{~km}$ from the current coastline.

Figure 8 shows modeled habitat uses of megalodon estimated for juvenile and adult using extant Carcharodon carcharias as references. The juvenile was more common on the coast at depth of 0-40 $\mathrm{m}$ in comparison to an adult. Whereas habitat use preference by adult megalodon was low at this depth but Andriwibowo et al. increasing at depth of 40-80 m. Juvenile and adult habitat use frequencies were low at a depth of between $80 \mathrm{~m}$ and $160 \mathrm{~m}$. Habitat use preferences were increasing at a depth of $>200 \mathrm{~m}$ (Figure 9).
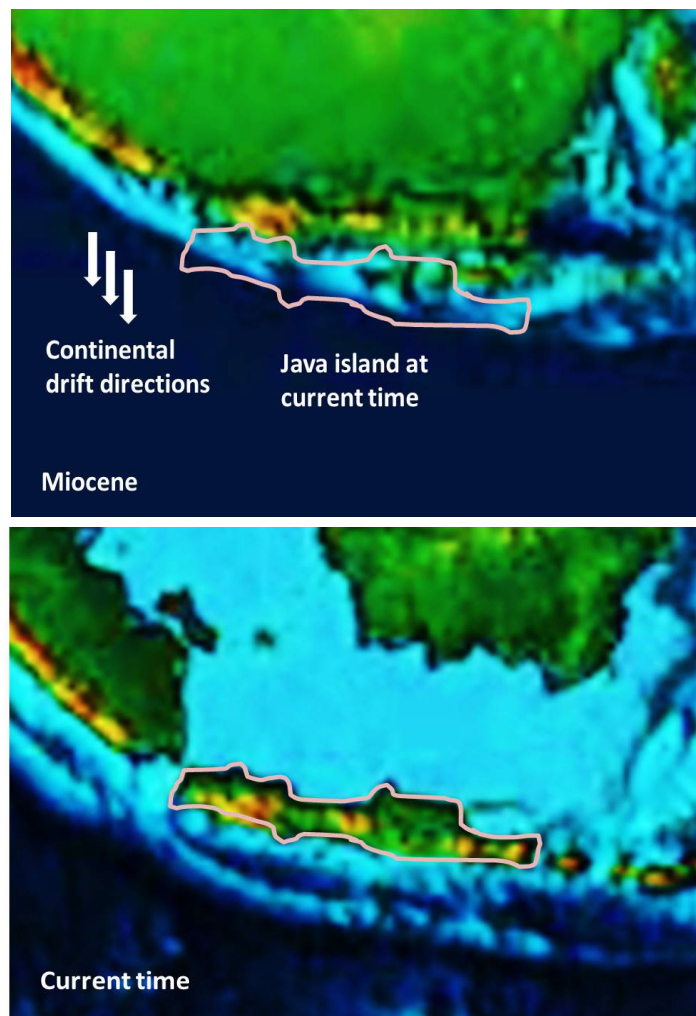

Figure 5. Java Island during Miocene period 20 million years ago 


\section{JURNAL BIODJATI}

http://journal.uinsgd.ac.id/index.php/biodjati
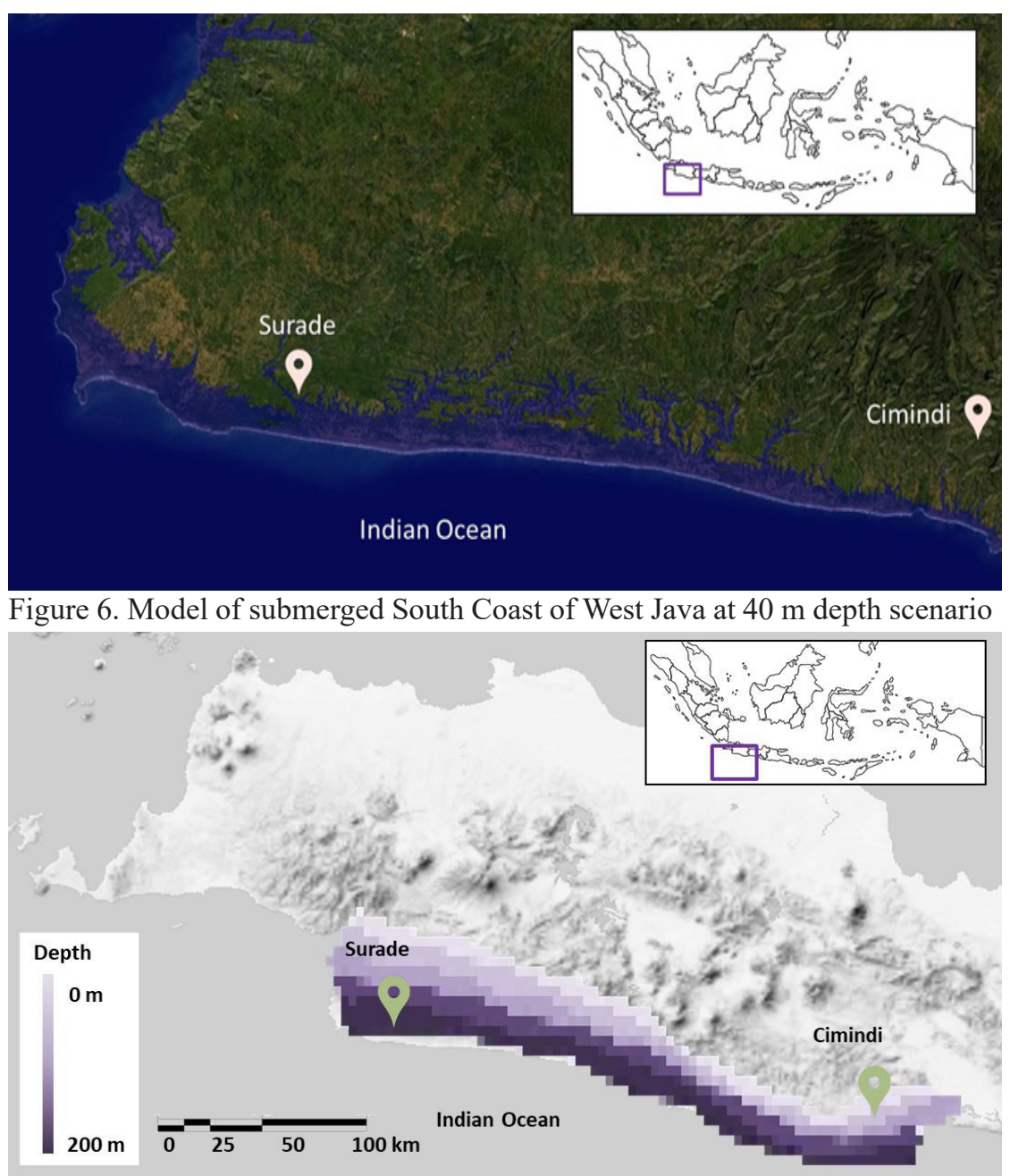

Figure 7. Bathymetry model of submerged South Coast of West Java during Miocene period.

The presences of megalodon in the South Coast of West Java represented by teeth fossils were comparable to other studies. Java Island was inhabited by numerous prehistoric shark species. Yudha et al. (2018) have reported findings of teeth representing 11 shark genera from 7 shark families sampled from coasts and inland. Those genera included Carcharhinus. Negaprion, Galeocerdo, Scoliodon, Sphyrna, Hemipristis. Alopias. Carcharias, Parotodus, Isurus, and Carcharodon. Even Yondri et al. (2020) have excavated remnants of shark teeth from Pawon Cave that was located as far as 75 $\mathrm{km}$ from the current South Coast of West Java. The soil and rock layers where the megalodon Jurnal Biodjati 6(2):264-272, November 2021 fossil was found were also comparable to the periods when megalodon exist as reported by other literature that is from the Miocene to the Pliocene (23-2.6 Ma) (Reolid \& Molina, 2015). Periods of soil layers in Surade and Cimindi were estimated from the Miocene period.

Habitat preferences of megalodon were modeled using extant great white sharks as an analog. Based on the model in this study, shallow shelf water was considered as the preferred habitat. Sharks mostly remained within shelf waters in depths $<100 \mathrm{~m}$ with occasional dives to depths $>1000$ m (Baleytó, et al. 2021). During the Miocene period, the 


\section{JURNAL BIDDJATI}

http://journal.uinsgd.ac.id/index.php/biodjati

megalodon was estimated to have traveled to the deepest parts of the Indian Ocean located on the South Coast of West Java. As a comparison, the extant great white shark has traveled over a long distance exceeding an estimated $1000 \mathrm{~km}$ in length (Bradford, et al. 2020). Megalodon juvenile was modeled as having higher habitat preferences at shallow water near the coast and at depth of $>200$ $\mathrm{m}$. Shallow water near the coast was known as the preferred nursery ground for juvenile megalodon (Pimiento, et al. 2010). Based on observation of extant sharks, Weng et al. (2007) have reported juvenile sharks have occasionally displayed deeper movements and vertical excursions reaching a depth of $226 \mathrm{~m}$. Shallow water excursions at depth of $26 \mathrm{~m}$ were observed mainly during dawn, day, and dusk. Whereas, an increase in the use of deeper waters by sharks is more frequent in adults (Curtis, et al. 2014). Kocsis \& Razak (2018) stated that megalodon juvenile prefers shallow marine coastal settings either looking for accessible food resource including smaller sharks, rays, and bony fishes and avoiding larger predators including adult megalodon or toothed whales. In contrast, adult megalodon likes other extant sharks, are able to explore deeper seas because adult sharks haves thermoregulatory capacity that allows them to tolerate colder waters better than juveniles (Baleytó, et al. 2021).

Declining of the megalodon population has been reported globally. The onset of the megalodon population decline probably started in the late Miocene with a decrease in its global abundance, followed by a decline in its geographical range during the Pliocene (Boessenecker, et al. 2019). Population decline of megalodon has been attributed to intertwined climate change and drop in the diversity of filter-feeding whales as the primary factors and the appearance of new competitors (large predatory whales and the great white shark) as secondary factors (Pimiento, et al. 2016). Considering its size, megalodon required ample prey as its diet. Megalodon that inhabiting the southern hemisphere including the Indian Ocean was estimated larger than the megalodon living in the northern hemisphere (Pimiento \& Balk, 2015). The megalodon population decline was an impact of declining prey caused by climate change. At prehistoric times, whales were the megalodon's prey (Goodfrey, et al. 2021). At the beginning of the Miocene, the diversity and abundance of marine mammals including small whales were high. Whereas, later during the Pliocene, there was a climate change in the form of a drop in ocean temperatures that likely contributed to the decline of megalodon preys followed by megalodon populations (Pimiento \& Clements, 2014).

Post middle Miocene oceanographic climate changes and cooling sea surface temperature may have resulted in megalodon range fragmentation, alongside competition with the newly evolved great white shark (Carcharodon carcharias) have also contributed to the megalodon population declines (Boessenecker, et al. 2019). Post middle Miocene oceanographic and sea surface temperature cooling as determinant factors are more significant mainly in South East Asia water in the form of winter monsoon (Holbourn, et al. 2018). Based on a highresolution benthic isotope record combined with paired mixed layer isotope and $\mathrm{Mg} / \mathrm{Ca}$ derived temperature data, a long-term cooling trend synchronized with the intensification of the Asian winter monsoon from 7 Ma until 5.5 Ma have been detected. Changes in the carbon cycle involving the terrestrial and deep ocean carbon reservoirs were determinant factors of Miocene climate cooling. 
Jurnal Biodjati 6(2):264-272, November 2021

\section{JURNAL BIODJATI}

http://journal.uinsgd.ac.id/index.php/biodjati
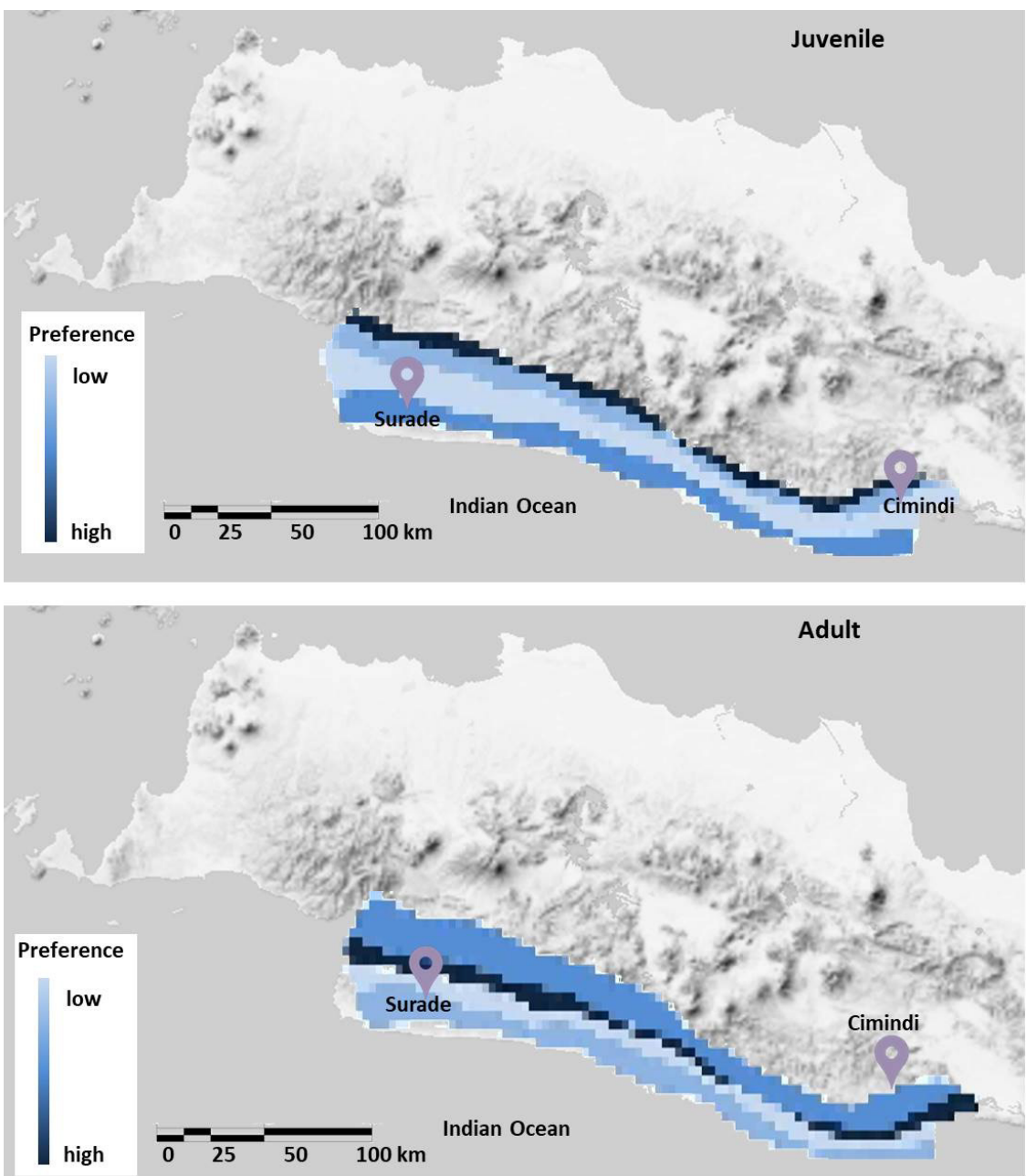

Figure 8. Habitat preference model of juvenile (top) and adult (bottom) megalodon in South Coast of West Java during Miocene period

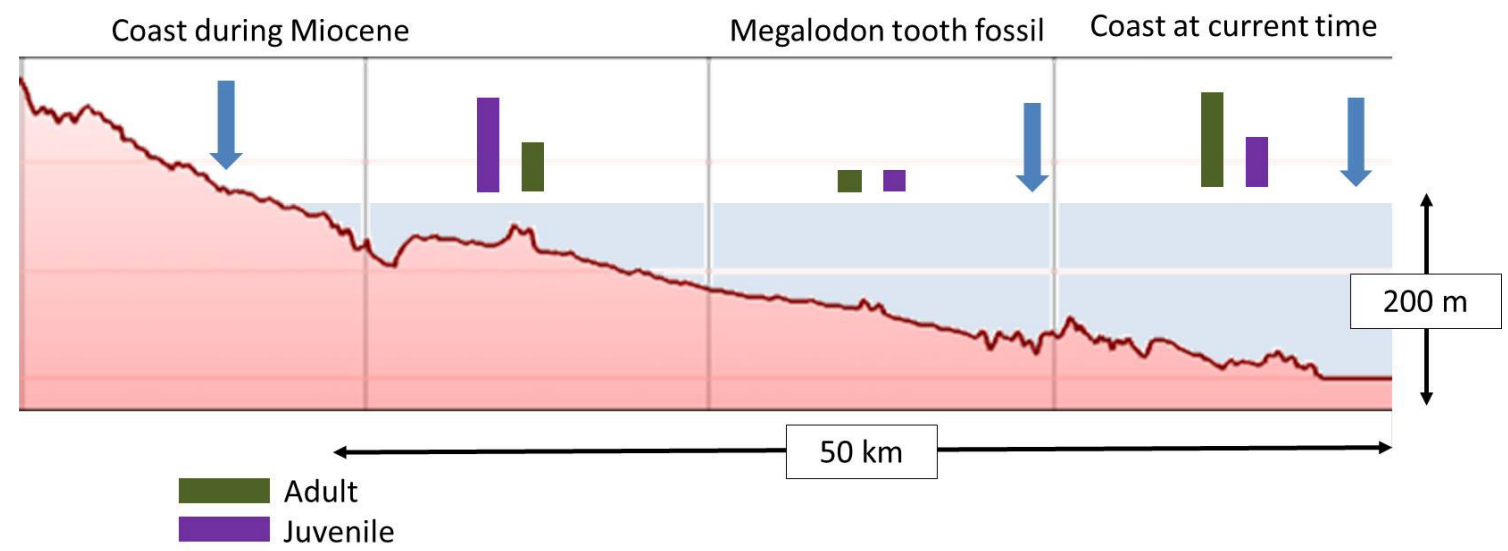

Figure 9. Habitat preference model of juvenile and adult megalodon in South Coast of West Java during Miocene period (cross sectional view) 


\section{JURNAL BIDDJATI}

http://journal.uinsgd.ac.id/index.php/biodjati

\section{ACKNOWLEDGEMENTS}

We are deeply indebted to the many stakeholders including the local community of Cimindi dan Suradi Villages and curators that have contributed to the preservations of the shark fossils and facilitated the excavation process.

\section{REFERENCES}

Azizah, B. (2020). Geologi dan Potensi Batuan Tufa Sebagai Bahan Baku Industri Daerah Karangmekar dan Sekitarnya Kecamatan Karangnunggal Kabupaten Tasikmalaya, Provinsi Jawa Barat. JOM Bidang Teknik Geologi, 1(1), 1-14.

Baleytó, M.A., Leos-Barajas, V., Adam, T., Hoyos, M., Santana-Morales, O., Galván-Magaña, F., Armas, G.R., Lowe, C., Ketchum, J. \& Villalobos, H. (2021). Diving Deeper Into the Underlying white Shark Behaviors at Guadalupe Island, Mexico. Ecology and Evolution. 11(21), 1-18.

Boessenecker, R., Ehret, D., Long, D.,Churchill, M., Boessenecker, S., \& Martin, E. (2019). The Early Pliocene extinction of the mega-toothed shark Otodus megalodon: a View from the Eastern North Pacific. PeerJ, 7.

Bradford, R., Patterson, T.A. \& Rogers, P.J. (2020). Evidence of Diverse Movement Strategies and Habitat Use by white Sharks, Carcharodon carcharias, off Southern Australia. Mar Biol, 167(96), $1-12 .$.

Cooper, J.A., Pimiento, C., Ferrón, H.G. et al. (2020). Body Dimensions of the Extinct Giant Shark Otodus megalodon: a 2D reconstruction. Sci Rep, 10(1), 14596.

Curtis, T.H., McCandless, C.T., Carlson, J.K., Skomal, G.B., Kohler, N.E. \& Natanson,
L. (2014). Seasonal Distribution and Historic Trends in Abundance of White Sharks, Carcharodon carcharias, in the Western North Atlantic Ocean. PLoS ONE, 9(6).

Gaffar, E. Z. 2017. Subsurface Geological Structure In South Garut Based On Electromagnetic Data. Ris.Geo.Tam, 27(2), 123-131.

Godfrey, S., Nance, J. \& Riker, N. (2021). Carcharocles-bitten Sperm Whale Tooth from the Neogene of the Coastal Eastern United States. Acta Palaeontologica Polonica, 66.

Herraiz, J.L., Ribé, J., Héctor, B., Carlos, M., \& Humberto, F. (2020). Use of Nursery Areas by the Extinct Megatooth Shark Otodus megalodon (Chondrichthyes: Lamniformes). Biol. Lett.16(11).

Holbourn, A.E., Kuhnt, W. \& Clemens, S.C. (2018). Late Miocene Climate Cooling and Intensification of Southeast Asian Winter Monsoon. Nat Commun, 9, 1584.

Keyes, I. W. (1972). New Records of the Elasmobranch C. megalodon (Agassiz) and a Review of the Genus Carcharodon in the New Zealand Fossil Record. New Zealand Journal of Geology and Geophysics, 15(2), 228-242.

Kocsis, L. \& Razak, H. (2018). Late Miocene Otodus (Megaselachus) megalodon from Brunei Darussalam: Body Length Estimation and Habitat Reconstruction. Neues Jahrbuch für Geologie und Paläontologie - Abhandlungen, 288, 299-306.

Levy, Y., Goring-Morris, N. A. \& Yechieli, Y. (2019). Harnessing Paleohydrologic Modeling to Solve a Prehistoric Mystery. Sci Rep, 9, 16349.

Perez, V., Leder, R. \& Badaut, T. (2021). Body Length Estimation of Neogene 


\section{JURNAL BIDDJATI}

http://journal.uinsgd.ac.id/index.php/biodjati

Macrophagous Lamniform Sharks (Carcharodon and Otodus) Derived from Associated Fossil dentitions. Palaeontologia Electronica, 24(1), $1-12$.

Pimiento, C., Ehret, D., Macfadden, B. \& Hubbell, G. (2010). Ancient Nursery Area for the Extinct Giant Shark Megalodon from the Miocene of Panama. PloS one. 5(5), e10552

Pimiento, C., \& Clements, C.F. (2014). When Did Carcharocles megalodon Become Extinct? a New Analysis of the Fossil Record. PLoS ONE, 9(10), e111086.

Pimiento, C. \& Balk, M.A. (2015). BodySize Trends of The Extinct Giant Shark Carcharocles megalodon: a Deep-time Perspective on Marine Apex Predators. Paleobiology, 41(3), 479-490.

Pimiento, C., MacFadden, B., Clements, C., Varela, S., Jaramillo, C., Velez-Juarbe, J. \& Silliman, B. (2016). Geographical Distribution Patterns of Carcharocles megalodon Over Time Reveal Clues About Extinction Mechanisms. Journal of Biogeography, 43(8), 1645-1655.

Reolid, M. \& Molina, J. (2015). Record of Carcharocles megalodon in the Eastern Guadalquivir Basin (Upper Miocene, South Spain). Estudios Geológicos, 71, (2): e032

Satria, D., Ramadhani, R., Suriyanto, R., Novian, M.. (2018). The Diversity of Sharks Fossils in Plio-Pleistocene of Java, Indonesia. AIP Conference Proceedings. 2002. 1-12.

Syahied, F.I., Noor, D. \& Ridwansyah, I. (2020). Geologi Daerah Simpang dan
Sekitarnya Kecamatan Karangnunggal Kabupaten Tasikmalaya, Provinsi Jawa Barat dan Potensi Kerentanan Pencemaran Air Tanah Dangkal di Das Situ Rawa Gede Desa Sirna Jaya Kecamatan Sukamakmur, Kabupaten Bogor, Provinsi Jawa Barat. JOM Bidang Teknik Geologi, 1(1).

Trif, N., Ciobanu, R. \& Vlad, C. (2016). The First Record of the Giant Shark Otodus megalodon (Agassiz, 1835) from Romania. Brukenthal Acta Musei, XI, 507-526.

Veatch, E. G., Tocheri, M.W., Sutikna, T., McGrath, K., Saptomo, E.W., Jatmiko, \& Helgen, K.M. (2019). Temporal Shifts in the Distribution of Murine Rodent Body Size Classes at Liang Bua (Flores, Indonesia) Reveal New Insights Into the Paleoecology of Homo floresiensis and Associated Fauna. Journal of Human Evolution, 130, 45-60.

Yondri. L., Oscandar, F., \& Malinda, Y. 2020.Utilization of marine resources in prehistoric era at Pawon Cave West Java. IOP Conf. Series: Earth and Environmental Science, 584, 1-8.

Yudha, D. S., Ramadhani, R., Suriyanto, R.A. \& Novian, M.I. (2018). The diversity of Sharks Fossils in Plio-Pleistocene of Java, Indonesia. AIP Conference Proceedings 2002(1), 1-8.

Weng, K., Lowe, C., Winkler, C. \& Block B. 2007. Movements, Behavior and Habitat Preferences of Juvenile White Sharks Carcharodon carcharias in the Eastern Pacific. Marine Ecologyprogress Series, 338, 211-224. 